\title{
Chapter 2 \\ Remaining Central and Interdisciplinary: \\ Conditions for Success of a Research Speciality at the University of Strasbourg (1961-2011)
}

\author{
Marianne Noël
}

\subsection{Background and Context}

Chemistry is a good example of how modern research is organised in an impressive array of sub-disciplines and hybrid discipline formations, interdisciplinary collaborations, and new experimental systems based on specific methodologies, techniques, and substrates (Meinel in Reinhardt 2001, p. IX). The eclectic mix of objectives, ideas, practices, and ways of thinking that defines chemistry as a science, a profession, or an industry has shaped its academic perception. Bensaude-Vincent and Simon (2008, p. 3) argue that "chemistry "is an "impure science"; that it mixes science with technological applications, that it eschews high theory, and that it does not hold consistency to be its highest value'. Its hybrid nature, its common interest in the material world, its persistent faith in empirical generalisations instead of rigorous mathematical models (Kovac 2002), and its adhesion to metaphysical constructs (van Brakel 2000) have often put chemistry in a subaltern position in comparison to other sciences, particularly physics. Even as it first established itself as an independent scientific discipline in the eighteenth century, chemistry was regarded as being intellectually inferior to mathematics and physics (Bensaude-Vincent and Simon 2008, p. 3). Stichweh (2001) depicts disciplines as the primary unit of the internal differentiation of science in the late eighteenth and early nineteenth centuries and considers the continuous mutual observation and interaction of disciplines as the most important factor in the dynamics of modern science. In this respect, this chapter addresses the question of how chemists find their place among the many already established positions in the world of research, and, more specifically, what their positioning practices are when they develop new research specialities.

M. Noël (四)

LISIS, Univ Gustave Eiffel, ESIEE Paris, CNRS, INRAE, Marne-la-Vallée, France

e-mail: noel@ifris.org 
In this chapter, I discuss the development of a research specialty (supramolecular chemistry or SMC) at the University of Strasbourg (France). As it is practised today, SMC is one of the most vigorous and fast-growing fields of chemical endeavours (Steed and Atwood 2009). From the perspective of social studies of science, its history still remains to be written. ${ }^{1}$

This study focuses mainly on the work carried out by and around Nobel Prize laureate Jean-Marie Lehn. Lehn spent the better part of his career in Strasbourg, the university where he had studied. This place is indeed extremely interesting as prestigious awards have been won over a short period of time: Jules Hoffmann (Nobel Prize in Physiology or Medicine in 2011), Martin Karplus (Nobel Prize in Chemistry in 2013) and Jean-Pierre Sauvage (Nobel Prize in Chemistry in 2016) have all developed their research programmes in Strasbourg.

What are the conditions for the success of 'Strasbourg's chemistry'? As Lehn himself stressed, 'Chemistry in Strasbourg, just like the University as a whole, is the product of its history and geography'. ${ }^{2}$ In this chapter, I take a socio-historical approach whereby SMC is both a concept and a social object, embedded in an institutional context and shaped by professionals and scientific policies. In so doing, I place the sociology of knowledge in a broader perspective (Bonneuil and Pestre 2015) and examine how historical analyses can help improve our understanding of community in ongoing disciplinary formations. Within this institutional context (a university setting), the disciplinary framework can't be ignored as disciplines constitute the educational units of organisation (Whitley 1976).

In Strasbourg, the development of SMC has led to the creation of a dedicated institute (a new building) on the university campus, demonstrating a large degree of permanence and legitimacy. Interestingly, this has occurred in a highly centralised state (France), where implementation of an interdisciplinary programme in materials research failed (Bertrand and Bensaude-Vincent 2011). Drawing on historical work devoted to the University of Strasbourg, I will also characterise this singularity.

\subsubsection{Revisiting the Emergence of Research Specialties in Chemistry}

For reasons similar to those detailed by Raimbault and Joly in their contribution to this book (2021), I consider the notion of discipline as a relevant analytical entry point. In the history of modern chemistry, much attention has been paid to the ways in which chemists demarcated their domain from other domains as well as to their insistence on a chemical epistemology and systems of chemical language and

\footnotetext{
${ }^{1}$ With the exception of Schummer (2006) referring to an unpublished manuscript (footnote 6).

${ }^{2}$ FR Service Archives de l'Université de Strasbourg/Guy Ourisson/GO 150/Centre de Recherche en Chimie de l'Université Louis Pasteur: plaquette de présentation. 'La chimie à Strasbourg', par JeanMarie Lehn, préface de la plaquette (1992).
} 
imageries (Nye 1993, p. 3). Chemistry stands out as a distinct space in which research follows a logic of cohabitation, thus comparable to the engineering sciences (Bensaude-Vincent and Stengers 2001). Apart from a few notable cases (for instance Gavroglou and Simões (2012) who qualify quantum chemistry as an 'in-between discipline', 'neither physics nor chemistry'), this emphasis on demarcation corresponds with the treatment of disciplines by many sociologists and historians of science who focused on the organisation of nineteenth and early twentieth-century academic scholarship. The underlying 'discipline model' which holds that scientific growth unfolds as a process of differentiation into new specialties and disciplines has recently been challenged in the literature (see Heinze et al. (2013) for a review).

As for epistemic and social patterns of emergence, a fair amount of work on scientific disciplines and their development was carried out in the 1960s and 1970s (for instance, Lemaine 1976), complemented later on by research focusing specifically on chemistry (Nye 1993; Reinhardt 2001).

Two more recent studies are devoted to the emergence of research specialties in France, thereby opting for a concept less rigorous than the established notion of 'discipline'. Voillequin (2008) examines the case of catalysis (1944-2004), which he sees as a paradigmatic case of a techno-science emerging at the crossroads of disciplines. His history of catalysis tells the story of a community in search of legitimacy, aware of the transepistemic importance of its scientific domain (particularly given its ties to industry), constantly wavering between efforts to open up and a tendency towards confinement. In the case of solid-state chemistry, Teissier (2010) provides a model that extends from the formation of a community in the 1930s to its scattering in 2004. Both authors focus on the institutional construction of laboratories and draw on the journey of the 'masters' and the fate of their respective schools of research.

The concept of research schools has prevailed as a cornerstone of reflection on modern chemistry (Servos 1993). It places competition at the heart of the dynamics of scientific activities. The collective in-the-making is presented as a set of competing individuals addressing the subject from incompatible points of view. This latter conception thus offers a rather restricted theoretical frame and runs the danger of wrongfully neglecting contextual factors in the emergence of a specialty, especially the role of pre-existing entities and prevalent social rules.

In this chapter, I consider all three conceptions-that of a discipline, of a research specialty, and of a research school. In the following section, I shortly introduce the classical study of the emergence of molecular biology as a research specialty by Mullins (1972); I refer to Stichweh's (2001) take on the rise of disciplinarity in the formative period of the eighteenth and nineteenth centuries; I then depict how the historical conception of science as organised in disciplinary structures has been adapted to contemporary contexts by Marcovich and Shinn's (2011) notion of a 'new disciplinarity' and how the focus on individual founders of research schools can be replaced by considering a variety of typical trajectories of technoscientific practitioners in the context of a 'new disciplinarity', as put forward by Marcovich 
and Shinn (2014). Based on this theoretical outline, I present my own empirical case-namely the emergence of supramolecular chemistry in France—and discuss its fit with the presented theoretical approaches.

\title{
2.1.2 The Role of Individual Scientists, Coherent Groups, Disciplines and New Disciplinarity
}

Mullins (1972) not only provided a useful definition and characterisation of specialities as

\begin{abstract}
an institutional cluster which has developed regular processes for training and recruitment into roles which are institutionally defined as belonging to that specialty. Members are aware of each other's work, although not necessarily deeply involved in communications with one another. They may share a paradigm and a set of judgements about what general work should be done in the field, although the details of those ideas might differ. The specialty, then, has many aspects of a formal organisation, i.e., recruitment procedures, tests of membership, journals, meetings, etc., and the locations which support its work become much more important than they were at earlier stages. (Mullins 1972, p. 74)
\end{abstract}

$\mathrm{He}$ also presented a model of scholarly knowledge development in four stages with distinct, empirically traceable characteristics. The four stages are considered as non-exclusive but sequential patterns that scientific communities exhibit. The importance (and success) of Mullins' model lies in the fact that it combines social and cognitive aspects, including group formation and change. It regards 'coherent groups' as the primary drivers of scientific change (Griffith and Mullins 1972), although neglecting the overall complexity of group dynamics. Building on Mullins' model provides my own analysis with an option to address temporal stratification constituted by various collective mechanisms as well as with the potential to recognise the role of individual researchers and relating groups of researchers. The temporality introduced by Mullins' model is also constitutive of the 'new disciplinarity' put forward much later by Marcovich and Shinn.

To understand 'new disciplinarity' it is first necessary to trace the conception of disciplinarity as it developed in the 1980s and 1990s. For this short overview it should suffice to refer to the historical analysis put forward by Stichweh (1984, 2013). Informed by systems theory, Stichweh traces the emergence of (sub)disciplinary structures within science, conceived of as a system in constant differentiation during the period his historical study focused on—namely, 1740 to 1890 . It is also noteworthy that Stichweh initially focused on physics, which was perceived as a paradigmatic discipline at that time. In the same period, disciplinarity began to be seen as potentially problematic, and debates about disciplinarity, interdisciplinarity, and transdisciplinarity ensued. Around the turn of the last century, a growing number of scholars began to challenge disciplinarity as a valid analytical concept, devising new terms such as 'inter-disciplines' (Weber 2010). As a result, attention seemed to shift away from disciplines back to specialties, research schools, networks, and prominent individuals. 
In 2011, Marcovich and Shinn expanded on these discussions by introducing the notion of 'new disciplinarity' as a product of the growing complexity of knowledge and scientific activity. This notion reinstates disciplinary entities as valid points of reference ${ }^{3}$ but also highlights the changing prominence of combinatorials, ${ }^{4}$ projects, ${ }^{5}$ borderlands, ${ }^{6}$ displacement, ${ }^{7}$ and temporality ${ }^{8}$ (Marcovich and Shinn 2011, 2014). The authors first look at the trajectory of Max Delbrück and the phage group as well as the journey of other scientists who, like Delbrück, came from quantum mechanics. They develop the idea that molecular biology was born from a problemdriven combination of multiple projects with a disciplinary grounding, ultimately converging in a concatenation. In this 'new disciplinarity', disciplines remain a practitioner's point of reference, even when he/she "occupies a "borderland" constituted by research projects that engage alternative specialties' (Marcovich and Shinn 2011, p. 584). The border is understood as a process, a place of convergence, exchange, and creation, not as a simple dividing line (Newman 2006). Marcovich and Shinn (2014) recently further refined their concept. Based on interviews of 47 scientists engaged in nanoscale research in multiple areas of physics and life sciences, they defined four typical trajectories of nanoscale practitioners: (1) beckoning from indoors; (2) extending the repertory; (3) common territory for answering homeland questions; and (4) successive projects, which intertwine the six elements explained above.

\subsubsection{Approach, Methods and Structure of this Chapter}

In the ensuing case study of the emergence of supramolecular chemistry (SMC), I focus on a group of chemists (3 Nobel laureates and their collaborators) that I call a 'paradigm group', resonating with an earlier conception of 'schools of research' and

\footnotetext{
${ }^{36}$ Disciplines constitute the stable referent of practitioners, providing the intellectual and material resources, language and universe of questions.' (Marcovich and Shinn 2014, p. 172).

${ }^{4}$ 'Combinatorials are the association of elements (instruments, materials, concepts and people) whose novel integration often constitutes powerful resources for extending problem solving.' (Marcovich and Shinn 2014, p. 174).

${ }^{5}$ 'Projects are to be understood as a crystallisation of questions that are asked in the framework of a discipline but which require resources belonging to other disciplines in order to solve a problem.' (Marcovich and Shinn 2014, p. 175).

${ }^{6}$ The borderland is conceived of as 'an indefinite, fuzzy, narrow swath of terrain contiguous with the well-defined territory of two recognized entities, in our case scientific disciplines.' (Marcovich and Shinn 2014, p. 176).

${ }^{7}$ 'Displacement refers to a selective intermittent movement of a scientist into the borderland of his discipline and a subsequent retreat from that terrain.' (Marcovich and Shinn 2011, p. 587).

${ }^{8}$ Temporality relates disciplinary landscapes (with a long-term temporality) to temporal projects (with a short-term temporality) by tracing processes of practitioner displacement. (Marcovich and Shinn 2011, p. 598).
} 
Mullins' notion of 'paradigm groups'. ${ }^{9}$ I make use of scientometric tools and trace the co-authorship patterns of a central actor to develop an analytical and sequential model in three periods, building on Mullin's phase model. I also trace the development of SMC as an example of 'new disciplinarity' in action, starting from the trajectory of a prolific and reflexive actor (Jean-Marie Lehn) whose career is marked by a series of shifts or displacements, potentially in line with Marcovich and Shinn's typology. I have particular interest in trajectory (1) (defined as 'traditional' and therefore opposed to a 'new disciplinarity') which for Marcovich and Shinn was originally exemplified by J. Fraser Stoddart, a major actor in SMC, whose research they described as 'remarkably self-referential' as 'he deal[t] endlessly with the same objects and in the same perspective' (Marcovich and Shinn 2014, p. 180). I then discuss whether there are differences in Stoddart and Lehn's respective trajectories and strategies and whether SMC can be positioned within the general framework of a 'new disciplinarity'.

The empirical materials I draw upon for this chapter are the following: for the historical part, I rely on the substantial material underpinning growth of the SMCreview articles,${ }^{10}$ textbooks, publications-including two publications specifically dedicated to the emergence of SMC (Gale 2000; Vicens and Vicens 2011)—press releases, and annual reports. I paid special attention to the Nobel lectures for their biographical richness. I also consulted archives stored at the University of Strasbourg documenting the whole career of Guy Ourisson. ${ }^{11}$ For the most recent period, I draw on fieldwork carried out in Strasbourg as part of a wider study (the ANR project PrestEnce), which is supplemented by interviews in Paris and Bordeaux. Twenty-eight semi-structured interviews were collected between April 2010 and November 2013 (25 professors, ${ }^{12}$ researchers, or staff belonging to the University and three external interviewees). They were tape-recorded then fully transcribed and

\footnotetext{
${ }^{9}$ A paradigm group is the minimal form of a scientific group. Its members have no necessary social connections. [...] The minimal requirement of such an entity is two or more established scientists who have shifted from one viewpoint to another (Gestalt shift), and who might or might not be in communication with one another.' (Mullins 1972, 54-55). The paradigm group equates its first step in the proposed four-stage model.

${ }^{10}$ There are more than 3600 review articles indexed in the Web of Science that match the query condition 'Topic $=$ Supramolecular chemistry'.

${ }^{11}$ Guy Ourisson (1926-2006) was a French chemist, a specialist in the chemistry of natural substances. He earned two doctorates, the first at Harvard University in 1952 and the second in Paris in 1954. In 1955, at the age of 29 years, he was appointed Professor at the University of Strasbourg, to which he remained faithful throughout his scientific career. In 1971, he was one of the first founders of the Louis Pasteur University in Strasbourg of which he was also the first president. He had numerous French and international awards and other distinctions. His specialisation was organic chemistry and he worked at the interface of organic chemistry and biology and later also at the interface of organic chemistry and geology (Rohmer 2006). Guy Ourisson has supervised many $\mathrm{PhD}$ theses, including that of Jean-Marie Lehn. The fonds Guy Ourisson entered the archives department of the Universite of Strasbourg in 2011. References: FR Service Archives de l'Université de Strasbourg/Guy Ourisson.

${ }^{12}$ For various reasons, I didn't interview the main actor (Jean-Marie Lehn).
} 
anonymised and lasted a range of 45 to 90 minutes. Some relevant excerpts of the transcripts are indicated by quotation marks.

The remainder of this chapter is structured as follows: I first present the concepts characteristic of the scientific programme of SMC and their genealogy. Based on Lehn's co-publications profile, I then draw on Mullins' four-step model to propose a three-period chronology. For each of the periods I explore modes of displacement and temporality that are constitutive of Marcovich and Shinn's 'new disciplinarity' and show these modes have a prominent collective dimension. Third, I look at this field's legacy through the organisational study of the Strasbourg chemistry department ${ }^{13}$ as it is currently configured. Fourth, I explore the role of architecture and geography. I focus on the ISIS building to illustrate its particular functions: a space that was originally designed to break down disciplinary boundaries and a 'transient' institution where promising young researchers could work before pursuing their career in other research centres. In doing so, I hope to reveal specific patterns of emergence and institutionalisation and show how this results in a new mode or conception of being together.

\subsection{SMC, a Speciality 'At the Borders Of'}

\subsubsection{Concepts Characteristic of the Scientific Programme of SMC}

What is SMC? The Larousse dictionary actually provides the following definition: it is a sub-discipline of chemistry which studies weak, non-covalent interactions between molecules. SMC is concerned with the complex entities formed by the association of two or several chemical species linked together by intermolecular forces, whereas molecular chemistry studies the properties of the entities made of atoms linked by covalent forces.

Jean-Marie Lehn was the first to lay its foundations and formalise its concepts in a seminal article published in 1978 (Lehn 1978). This work (especially the synthesis of cryptands performed in his laboratory ten years earlier) earned him the 1987 Nobel Prize for Chemistry, which he shared with Charles J. Pedersen (DuPont) and Donald J. Cram (University of California, Los Angeles) 'for their development and use of molecules with structure-specific interactions of high selectivity'.

SMC is a term coined by Lehn as the " chemistry beyond the molecule", bearing to the organised entities of higher complexities that result from the association of two

\footnotetext{
${ }^{13}$ The PrestEnce project endorses the hypothesis that universities and their components (the academic departments) should be considered as potential meso level order and action levels (Paradeise and Thoenig 2013). In France, academic departments in the strict sense of the word do not exist. In this case study, the chemistry department comprises faculty members and research fellows at the CNRS, about 250 permanents researchers grouped in the 'International Center for Frontier Research in Chemistry' created in 2007.
} 
Table 2.1 Number of occurrences of 'supramolecular' in the 1987 Nobel lectures of the three laureates

\begin{tabular}{l|l|l|l}
\hline Laureate & $\begin{array}{l}\text { Charles } \\
\text { J. Pedersen }\end{array}$ & Jean-Marie Lehn & Donald J. Cram \\
\hline $\begin{array}{l}\text { Title of the } \\
\text { Nobel lecture }\end{array}$ & $\begin{array}{l}\text { Discovery of } \\
\text { crown ethers }\end{array}$ & $\begin{array}{l}\text { Supramolecular chemistry - scope } \\
\text { and perspectives: Molecules - } \\
\text { Supermolecules - molecular devices }\end{array}$ & $\begin{array}{l}\text { The design of molec- } \\
\text { ular hosts, guests and } \\
\text { their complexes }\end{array}$ \\
\hline $\begin{array}{l}\text { Number and } \\
\text { types of } \\
\text { references }\end{array}$ & $\begin{array}{l}36 \text { (auto- } \\
\text { citations, } \\
\text { mainly } \\
\text { patents) }\end{array}$ & 193 (academic) & 54 (academic) \\
\hline $\begin{array}{l}\text { Number of } \\
\text { occurrences of } \\
\text { 'supramolecular' }\end{array}$ & 0 & 71 & 0 \\
\hline
\end{tabular}

or more chemical species held together by intermolecular forces' (Lehn 1987). In an editorial published on the occasion of the 50th anniversary of Pedersen's discovery, Lehn stated that he introduced the term SMC, 'which is now widely accepted and has deeply permeated chemical literature, in order to define, consolidate and generalise the areas of crown ether chemistry, host-guest chemistry and the chemistry of molecular recognition, thus allowing for the emergence of the concepts and perspectives offered' (Lehn 2017). As I will emphasise later, the vocabulary of the SMC stabilised quite late, while a small number of authors like Siegel (1996) or Dance (2003) still questioned its novelty and the usefulness of its concepts in the late 1990s.

Prominent aspects of Lehn's work are its intense concern with chemical semiotics and its wide scope. As show in Table 2.1, this translates into a massive presence of the term 'supramolecular' and a large number of references in Lehn's Nobel lecture compared to the other laureates.

In the late 1960s, a whole range of macro(poly)cyclic composites with spherical cavities were synthesised, and cryptands are now found in chemical product catalogues. After having explored the particular properties of these three-dimensional assemblies in catalysis and molecular recognition, for the transport of ions or molecules, Lehn and colleagues extended their research to the study of 'supramolecular' (a term introduced by Lehn in 1978) entities formed by self-organisation processes using molecular recognition to control and direct the spontaneous formation of complex architectures.

Supramolecular structures are a result of various noncovalent interactions, including electrostatic interactions, hydrogen bonding, van der Waals forces, hydrophobic interaction, coordination, etc., some of which are often cooperating in one supramolecular complex. More importantly, properties of the formed supramolecular complexes are far beyond summation of the individual components. The early 1990s saw the introduction of the notions of adaptation and evolution into chemistry, the extension of self-organisation processes to the selection of the species contributing to it, and the implementation of 'informed' chemical and dynamic diversity. Relying on the dynamic aspects of SMC (named 'by essence' a dynamic chemistry), Lehn 
proposed the definition of a general concept, covering molecular as well as supramolecular chemistry - that of Constitutional Dynamic Chemistry (CDC) which introduced a paradigm shift with respect to what he called constitutionally static chemistry (Lehn 2007).

Where does the specialty stand today? Around 20 to 30 per cent of publications in leading chemistry journals such as Angewandte Chemie, Chemical Communications, Chemistry: A European Journal, and The Journal of the American Chemical Society are concerned with the practical achievements arising from concepts and visions that have been developed in this domain ${ }^{14}$ (Diederich 2007). There are currently two facets to the specialty: one is oriented mainly towards synthesis, attempting to design constructions with given molecular bricks, while the other seeks to explain, understand, and partly control existing self-assemblages. The rise of SMC has also been accompanied by a development of new concepts and methods able to monitor the sometimes quite fast dynamics of supramolecular systems. With this, SMC has become fruitful also for other areas in chemistry.

\subsubsection{A Three-Period Chronology}

As with other specialities (see McCray (2005) on the existence of 'creation stories' that reconstruct the development of a particular idea or invention back to a singularity), SMC comes with narratives about its leaders and 'founding fathers'. In their textbook 'Supramolecular Chemistry', Steed and Atwood (2009) trace its roots to the early days of modern chemistry. In this study, I chose to start in the year of JeanMarie Lehn's first publications (1961) and cover a period of 50 years.

Jean-Marie Lehn is a prolific author (nearly 900 publications between 1961 and 2011), whose articles have been frequently and progressively cited to this day. ${ }^{15}$ Using co-authorship as a proxy for collegiality (Laudel 2002; Larivière et al. 2016), his co-publications profile is reproduced with the 'Demography' module of the CorText Manager tool. The module analyses a ttxt file built from a Web of Science request (set of 897 publications released between 1961 and 2011 (Noël 2019), 488 co-authors, number of co-authored publications $\geq 2) .{ }^{16}$ Lehn's co-publications profile (Fig. 2.1) identifies a set of co-authors, with whom he has primarly published

\footnotetext{
${ }^{14}$ This represents a considerable number of publications since a journal like the JACS publishes 16,000 articles per year.

${ }^{15}$ At the time of writing, his prospective article entitled 'Perspectives in SMC' published in 1990 in Angewandte Chemie has been cited 2767 times.

${ }^{16}$ The 'Demography' module of the CorText Manager tool developed by the IFRIS digital platform (http://www.cortext.net/projects/cortext-manager.html) treats each field of the corpus (authors, journals, terms, etc.) and follows the occurrence of the main elements, which vary in number (20 or 50) depending on the nature of the field. The results are presented as stacked area charts; moving averages are used with time series data to smooth out short-term fluctuations and highlight longer term trends.
} 


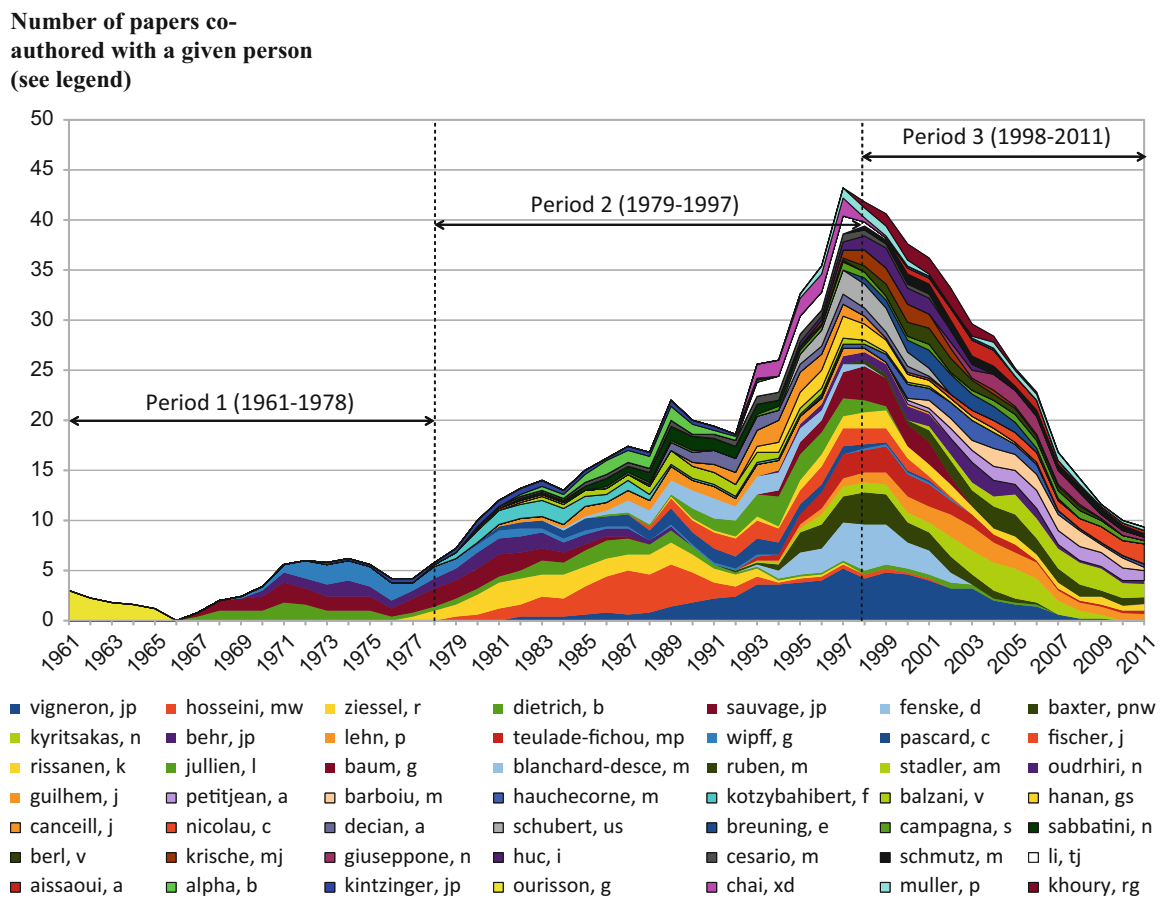

Fig. 2.1 Jean-Marie Lehn's co-publications profile (49 co-authors identified)

(49 names are extracted from a list of 488 co-authors). Their names and profiles are shown in different colours; for instance, on the left hand side of the graph one can see Ourisson's (Lehn's supervisor) contribution in yellow.

This profile features some interesting elements: first, there is an increase in the pace of co-authored publications at the turn of the 1990s (the slope, which seems quite stable since 1966, suddenly increases). This is probably related to the 'Nobel effect' but is also emblematic of the growing importance of teamwork and the increasing division of labour in contemporary chemistry (Cronin et al. 2004). Second, co-authors diversify in the most recent period: they are more numerous and different from those of the previous ones.

Based on slope variations of the profile, I have identified three periods of almost equal duration.

\subsubsection{Period 1: The Emergence of the Supramolecular Chemistry Paradigm (1961-1978)}

The 1960s, when Lehn entered the University, were a time of rapid growth of synthetic organic chemistry. After a thesis on triterpene NMR obtained under Ourisson's supervision, Jean-Marie Lehn left for a year to do a post-doc at Harvard, where he took part in the total synthesis of vitamin B12 (the most complex natural product synthesised to date), finally completed in 1971. Like so many other chemists 
of this period, Lehn was actively engaged in research related to organic synthesis. He participated in this landmark work in the history of organic chemistry that represented in his eyes 'the modern apogee' (Lehn 1980) since it showed that organic chemists were able to create very complex molecules by forming covalent bonds (Woodward 1973).

Upon his return from Harvard in 1964, Jean-Marie Lehn went to Strasbourg and entered the CNRS to create his own laboratory. He had become a recognised specialist in the use of NMR for understanding the physical properties of organic molecules. Searching for themes different to those he had studied with Ourisson and Woodward, he decided to direct his research towards physical chemistry. NMR studies of the movements of a liquid's molecules ensued. In parallel, he developed an entirely theoretical theme in his group: ab initio calculations of structural and conformational properties (Lehn in Kleinpeter and Eastes 2008).

In 1966, Lehn's interest turned to 'how a chemist might contribute to the study of ... highest biological functions' (Lehn 1987, p. 448). In this context, the first synthesis of crown ethers performed by Pedersen, an engineer for DuPont in 1967, supported his idea that it was possible for a cage molecule (which has a cavity) to capture another molecule with a complementary form. This led to the development of the chemistry of cryptands and cryptates in his laboratory.

The first cryptand was synthesised in September 1968 by two researchers doing their PhDs-Jean-Pierre Sauvage and Bernard Dietrich. It had been theoretically designed by Lehn by taking into account the little information available at that time on the complexation and transport of alkali metal ions by natural ionophores. It was a cage molecule, capable of selectively fixing a chemical substance (of the appropriate shape and size, in this case a potassium ion) in its cavity, called a crypt. The cryptand (from the Greek word kryptos meaning hidden) was a new molecular object, with a bond between the potassium ion and the crypt which had nothing to do with the covalent bond. Even though the first cryptand was synthesised 'by chance' (as mentioned in the closing lecture on 4 June $2010^{17}$ at the Collège de France), this situation was not artificial. The first direct proof of the cryptands' structure was provided by Raymond Weiss, professor at the University of Strasbourg since 1957, using X-ray diffraction techniques. ${ }^{18}$ In the following years the power of the concept of 'molecular recognition' and its generality were demonstrated.

Although Lehn made an effort to clarify terms in his 1978 publication, his definition of SMC remained unclear. Mullins (1972) sees this as a condition of emergence, the paradigm being an object to be adjusted and specified under new or stricter conditions.

For his part, Donald J. Cram at UCLA recognised that the work of C.J. Pedersen provided [him/them] 'an entree into a general field' (Cram 1987, p. 419). In his Nobel Lecture (1987, p. 419), he said: 'Although we tried to interest graduate students in synthesizing chiral crown ethers from 1968 on, the efforts were

\footnotetext{
${ }^{17} \mathrm{http}: / /$ www.college-de-france.fr/site/jean-marie-lehn/closing-lecture-2010-06-04.htm. Accessed 24 February 2019.

${ }^{18}$ It was a long-term task because at that time it took from six months to one year to determine the structure of a small molecule.
} 
unsuccessful. In 1970 we insisted that several postdoctoral co-workers enter the field'. By 1974, he published (with his wife, Dr. Jane M. Cram) a first general article entitled 'Host-Guest Chemistry' summarising their thoughts, methods, and results (Cram and Cram 1974). Along their definition, hosts are synthetic counterparts of the receptor sites of biological chemistry and guests the counterparts of substrates, inhibitors, or cofactors. He and his colleagues designed and prepared more than 1000 hosts, each with unique chemical and physical properties (Cram and Cram 1994). Cram underscored the importance of visualisation and the use of CoryPauling-Koltun (CPK) molecular models that provide better insights than the usual graphs, tables, and figures.

\subsubsection{Period 2: The Emergence of a Specialty: From Supramolecular Chemistry to a Science of Supramolecular Systems (1979-1997)}

The second period (1979-1997) consisted of two phases: the network phase followed by the cluster phase. In the network phase, certain participants recruited students. In groups of two or three, the scientists began to homogenise their vocabulary, to build fragments of a paradigm: the term 'molecular machine' was fully discussed for the first time in an article by V. Balzani, ${ }^{19}$ J. Fraser Stoddart, and collaborators in 1993. They also built new resources which contributed to the dynamic of their relationships: textbooks and curricula, originally written in mother tongue, became key components of the educational agenda. ${ }^{20} \mathrm{~A}$ host of collaborations developed and gave rise to co-publications. In 1987 Vincenzo Balzani gathered contributions (including those of Lehn and Pedersen) collected in a workshop on Capri Island in a textbook entitled 'Supramolecular Photochemistry'. Beyond Strasbourg, Lehn's network extended to colleagues at Collège de France (notably J.-P. Vigneron) where he was appointed in 1979, a position that gave him prestige and time to do research. The radial structure around Lehn expanded to form crosscutting branches between his former students and foreign colleagues-for instance M.W. Hosseini and R. Ziessel co-authored publications with V. Balzani. For their part, J.-P. Sauvage and B. Dietrich entered the CNRS in 1971 and 1974,

\footnotetext{
${ }^{19}$ Vincenzo Balzani is an Italian chemist, now emeritus professor at the University of Bologna. In 1984 he introduced the concepts of supramolecular chemistry in the field of coordination compounds, showing the possibility of controlling the photochemical and photophysical properties via an intelligent molecular architecture. Luminescent lanthanide ions complexes were the object of an intense collaboration with Jean-Marie Lehn; in particular Eu3+ and Tb3+ cryptates were considered examples of simple antenna systems. Together with Jean-Marie Lehn he defined supramolecular photochemistry as the incorporation of photoactive units in supramolecular structures, known as receptor/substrate complexes. There have been controversies in Italy considering the absence of Balzani, a pioneer in molecular machines, in the list of Nobel Prize winners in 2016.

${ }^{20}$ Aspects de la chimie des composés macrocycliques by B. Dietrich, P. Viout, and J.-M. Lehn, 1991; Supramolekular Chemie by F. Vögtle, 1989.
} 
respectively. The Strasbourg group has been able to stabilise, to develop, and recruit new members. Sauvage has developed his own line of research from 1983 onwards.

Mullins stresses the importance of the Cold Spring Harbor summer school as the 'melting pot' site. Part of the group (Atwood and Stoddart) considered the founding conference to have been the one organised in Jachranka, close to Warsaw in Poland. Although the 50 participants were overwhelmingly European, neither Jean-Marie Lehn nor his group was present. Jerry Atwood commented:

There was a key meeting in Poland in 1980 and that meeting formed the basis for the development of the field of supramolecular chemistry. It was one of those meetings where I knew no one when I went there; all of us came from different areas and in that week I made many of my best friends. ${ }^{21}$

In the cluster phase, decisive changes took place. There was a shift from network to a collective entity recognised and constituted as such by its members. The community produced a shared directory of resources: French and German textbooks were translated into English. This was the time of the creation of journals specifically dedicated to SMC (featuring programmatic editorials), some of them short-lived: the Journal of Inclusion Phenomena ${ }^{22}$ in 1983, Supramolecular Chemistry in 1992. Atwood organised a board of editors that ultimately produced an eleven-volume set (197 chapters, 6672 pages) which covered the gamut of this rapidly expanding area of research (Comprehensive Supramolecular Chemistry, Pergamon Oxford, 1996). For his part, Jean-Marie Lehn published Supramolecular Chemistry: Concepts and Perspectives in $1995 .^{23}$

Initiatives abounded, as the list of symposia on (and surrounding) SMC attests (Table 2.2). The topics covered include liposomes as well as nanogels or surface science. On that list we also find the first international summer school (a place where students were trained) organised in Strasbourg in 1990. The regular training of students presupposed the existence of job opportunities.

The group began to equip itself with more formal means of communication, thereby becoming a specialty. The resources created became increasingly collective and consubstantial with the group's existence: volume 11 of the manual mentioned above (Comprehensive Supramolecular Chemistry) is a cumulative subject index, further aiding the location of specific pieces of information. Between 1981 and 2000, Lehn himself devoted time to extended stays at European universities (as visiting professor in Cambridge, Barcelona, Frankfurt, Karlsruhe, Oxford, etc.) and at

\footnotetext{
${ }^{21}$ ChemComm, An Interview with Professor Jerry Atwood, 2012, https://web.archive.org/web/ 20121008094334/http://www.rsc.org/Publishing/Journals/cc/News/AtwoodInterview.asp.

Accessed February 24, 2019.

${ }^{22}$ Founded by J. Atwood in 1983, it became the Journal of Inclusion Phenomena and Macrocyclic Chemistry in 1999.

${ }^{23}$ The book was based on the Baker Lectures at Cornell University in 1978 and the Lezioni Lincee at Accademia Nazionale dei Lincei (Roma) in 1992. Today, it has been cited more than 12,000 times.
} 
Table 2.2 List of symposia on and surrounding SMC (1988-1997), extracted from the Memorandum of Understanding for the implementation of a European Concerted Research Action designated as COST Action D11

\begin{tabular}{|c|c|c|}
\hline Date & Conference & Location \\
\hline $\begin{array}{l}\text { September } \\
1988\end{array}$ & 13th International Symposium on Macrocyclic Chemistry & Hamburg, Germany \\
\hline $\begin{array}{l}\text { September } \\
1989\end{array}$ & Meeting on Organised Molecular Systems & Parma, Italy \\
\hline $\begin{array}{l}\text { September } \\
1990\end{array}$ & $\begin{array}{l}\text { First International Summer School on Supramolecular } \\
\text { Chemistry }\end{array}$ & Strasbourg, France \\
\hline July 1991 & Supramolecular Chemistry, Towards Self-Organisation & $\begin{array}{l}\text { Le Bischenberg, } \\
\text { Obernai, France }\end{array}$ \\
\hline 1991 & $\begin{array}{l}\text { EUCHEM Conference on Supramolecular Reactivity and } \\
\text { Catalysis }\end{array}$ & Padua, Italy \\
\hline May 1992 & $\begin{array}{l}\text { Micelles and Liposomes Research in Switzerland and } \\
\text { Europe }\end{array}$ & Zürich, Switzerland \\
\hline June 1994 & Supramolecular Structures and Self-replication & Maratea, Italy \\
\hline $\begin{array}{l}\text { August } \\
1994\end{array}$ & Research Conference on Supramolecular Chemistry & Mainz, Germany \\
\hline $\begin{array}{l}\text { September } \\
1995\end{array}$ & Liposomes: State of the Art & Freiburg, Germany \\
\hline March 1996 & $\begin{array}{l}\text { Nanogels and Sol-gel Processing: New Approaches } \\
\text { Towards better materials }\end{array}$ & Zürich, Switzerland \\
\hline June 1996 & 11th International Symposium on Surfactant in Solution & Jerusalem, Israel \\
\hline $\begin{array}{l}\text { September } \\
1996\end{array}$ & $\begin{array}{l}\text { Convegno Nazionale GICI, scienza e tecnologia dei sistemi } \\
\text { organizzati }\end{array}$ & Bari, Italy \\
\hline July 1997 & $\begin{array}{l}\text { 9th International Conference on Surface and Colloid } \\
\text { Science }\end{array}$ & Sofia, Bulgaria \\
\hline
\end{tabular}

${ }^{a}$ COST Action D11 Supramolecular chemistry (1999-2003) https://www.cost.eu/actions/D11/ \#tabsIName:overview.Accessedlhttps://www.cost.eu/actions/D11/\#tabsiName:overview.Accessed 24 February 2019

Harvard. His co-authorship pattern is much more diverse (particularly in the cluster phase as shown on Fig. 2.1) than it was before 1978.

Around 1996 the specialty stabilised. With the support of chemical learned societies, Jean-Marie Lehn created Chemistry: A European Journal, which became the main forum for SMC advances. Chemistry also stands out due to its 'concepts' section hosted since September 1996. One of the main aims of Chemistry was to highlight and support the outstanding research produced by groups across Europe.

As part of the European programme COST-chemistry, facilitated by a chemist from Toulouse, the D11 action $^{24}$ was launched in 1998, with funding that boosted the Strasbourg teams.

\footnotetext{
${ }^{24}$ Launched in 1971, COST is a pan-European intergovernmental initiative aimed at strengthening scientific and technical research in Europe by supporting cooperation between European researchers. COST is a networking instrument (it doesn't fund research itself). In 1990, a chemist from Toulouse, Gilbert Balavoine, was entrusted with chairing the COST-chemistry programme. COST Chemistry Actions were launched, numbered D1, D2, .. which try to cover as best as possible the scientific field of chemistry. D11 action gathered 60 research groups from some
} 


\subsubsection{Period 3: Institutionalisation Processes (1998-2011)— Materialising Concepts}

The third period was the post-Nobel Prize and institutionalisation period. Scientists moved from a project with an initial research question to another. Jean-Marie Lehn worked on many topics that shared one core research question: 'what does SMC mean?'. He endeavoured to materialise the concept of SMC in its successive senses and devoted part of his efforts to ensuring the long-term survival of the bodies created: the Supramolecular Science and Engineering Institute and the thematic network of advanced research (RTRA). ${ }^{25} \mathrm{He}$ was involved in many and diverse collaborations and travelled extensively.

In December 2011, ISIS counted nine laboratories and four industrial branches. This original structure is constituted of senior laboratories, headed by recognised and internationally renowned scientists, and junior laboratories, where researchers beginning their career develop independent research as part of a project that is not scheduled to last more than six years. ISIS stands out in the French research ecosystem: the recruitment of foreign professors on the international market concurs with the strong local roots of this organisation.

In 1987, Jean-Marie Lehn defined SMC as the 'chemistry beyond molecules'. It is a polysemic object, both a concept and a specialty, even a discipline, with the main characteristic of being situated 'at the borders of'. That is in fact the name (in French) of the RTRA (the Centre International de Recherche aux Frontières de la Chimie which has been translated as International Centre for Frontier Research in Chemistry).

\subsubsection{An Original Conceptual and Organisational 'Heritage'}

Which social processes encouraged the emergence of this specialty in Strasbourg? Based on my fieldwork and historical documents, I list a few of them, looking for patterns of a general scope.

20 European countries and was endowed around 40 million euros over 5 years. Balavoine's correspondence with Ourisson attests to the links maintained between the two researchers about this programme. (FR Service des archives de l'Université de Strasbourg; fonds Guy Ourisson; GO454; Programmes de coopération scientifique).

${ }^{25}$ The RTRA CIRFC (Centre International de Recherche aux Frontières de la Chimie) was created in 2006. The associated scientific research foundation FRC (Fondation pour la Recherche en Chimie) was established in 2007 with the University of Strasbourg, the CNRS, BASF-France, and Bruker-Biospin as funders and with the dotation of the Ministry of Higher Education and Research. The administration of the RTRA and of the foundation is located in the ISIS building, where the laboratory of its director is also localised. 


\subsubsection{A Polymorphic, Though Coherent and Organised Community, Attentive to Its Position}

From both inside and outside, chemistry is perceived as a coherent and organised entity: the multiple stories researchers shared collectively (from the awarding of the Nobel Prize to the national competition for RTRA) have nurtured the disciplinary framework. As Lehn mentioned in his Nobel Lecture, chemists in Strasbourg, as a whole, contributed to the Prize:

I wish to thank very warmly my collaborators at the Université Louis Pasteur in Strasbourg and at the College de France in Paris whose skill, dedication and enthusiasm, allowed the work described here to be realized. Starting with B. Dietrich et J.-P. Sauvage, they are too numerous to be named here, but they all have contributed to the common goal. (Lehn 1987, p. 484).

The community as a whole derived benefits from these successes. Today, the chemistry department (Faculté de Chimie) offers a wide range of specialties. As expressed by a high-level person with policy-making responsibilities at CNRS, 'it's a mosaic'. ${ }^{26}$ But for an executive head of the university,

compared to other disciplines, chemistry is easy to position: there are industrial partners, it has a good image within society ... a strong symbolic value with Jean-Marie Lehn. This introduces strong subjective elements, other than the quality of the person, the quality of the science which is done. It's simple with respect to the outside world. In communication efforts, when I say 'Jean-Marie Lehn Nobel Prize', it's very easy! ${ }^{27}$

This symbolic dimension has been undoubtedly strengthened by awarding the Nobel Prize to other chemists from (or affiliated with) Strasbourg whose work is more or less connected to that of Lehn and SMC. ${ }^{28}$ The quotation above shows that, despite the epistemic diversity of the department (a mosaic), the disciplinary framework created and creates a sense of unity. A sense of allegiance to chemistry, a characteristic of the discipline emphasised by Lenoir (1997, pp. 48-49), was coupled earlier in Lehn's discourse with attention to its centrality: 'Chemistry plays a central role both in the natural sciences and in knowledge, and in its economic importance and omnipresence in our daily lives' (Lehn 1980, emphasis by the author). This positioning practice of chemists, referring to chemistry as the central science, persists until today (Bertozzi 2015). It is not specific to Strasbourg but has undoubtedly been taken up in the emergence of SMC.

\footnotetext{
${ }^{26}$ Interview 2, 25/05/2012.

${ }^{27}$ Interview 3, 22/11/2011.

${ }^{28}$ I refer here to Jules Hoffmann (2011), Martin Karplus (2013), and Jean-Pierre Sauvage (2016). In his Nobel lecture, Sauvage explicitly thanked '[his] mentor and friend Jean-Marie Lehn, the teachers who had a strong influence on [his] scientific interests, Guy Ourisson and Raymond Weiss'.
} 


\subsubsection{A Strong Local Rootedness with Great International Openness}

The University's international openness can be rooted in its history (Craig 1984; Olivier-Utard 2010; Crawford and Olff-Nathan 2005). Following the annexation of Alsace-Moselle by Prussia, authorities encouraged the recruitment of foreign teachers from 1871 onwards. This was also the case after World War I, when Alsace came back under the auspices of the French State. A professor explained:

For more than 150 years, the University appeared to be sometimes French, sometimes German, sometimes French... . In its relation to Germany, France considered the University as a 'showcase' and the other way round. There are always been a recruitment of quality people. Since these early periods, people have been carefully selected to import researchers coming from abroad who settled here in Strasbourg. ${ }^{29}$

The aim was to build an exceptional setting, which remained extraneous to the local people and required a number of years to fully appropriate. As many testimonies collected during the fieldwork attested, there is still a large incongruity between foreign and locally-trained professors (the latter constituting a large part of interviewees in our sample). For instance, the need for teaching in French at the undergraduate level creates a clear differentiation in terms of access to master's programmes, which has been described as problematic by interviewees.

In addition to these features came the development of institutional structures (first the ISIS, then the RTRA) supported by stakeholders, especially in the Alsace Region. ${ }^{30}$ The Strasbourg members of the 'paradigm group' (almost all are members of the French Académie des Sciences) embedded knowledge within a political dimension, which gave it the power of both a social and a symbolic link (Jacob 2007). The Alsatian local rootedness translates into the capacity to act in and the service of the region as well as at the local, national, and international level. The career of Guy Ourisson, the 'ultimate godfather of Strasbourg chemistry', 31 is emblematic thereof.

\subsubsection{The ISIS Building as a Mediator Between Epistemic Practices and Politics}

In the late 1990s Lehn created the Supramolecular Science and Engineering Institute (Institut de Science et d'Ingénierie Supramoléculaire, ISIS), which was hosted in a new building from 2002 onwards. This institute was specifically designed for the

\footnotetext{
${ }^{29}$ Interview 4, 27/04/2010.

${ }^{30}$ Created in 1991, the Pôle universitaire européen de Strasbourg (European university centre in Strasbourg) symbolised the rapprochement of the three existing universities by associating them with the three local authorities (Alsace Region, Bas-Rhin department, Communauté Urbaine de Strasbourg).

${ }^{31}$ Interview 3, 22/11/2011.
} 


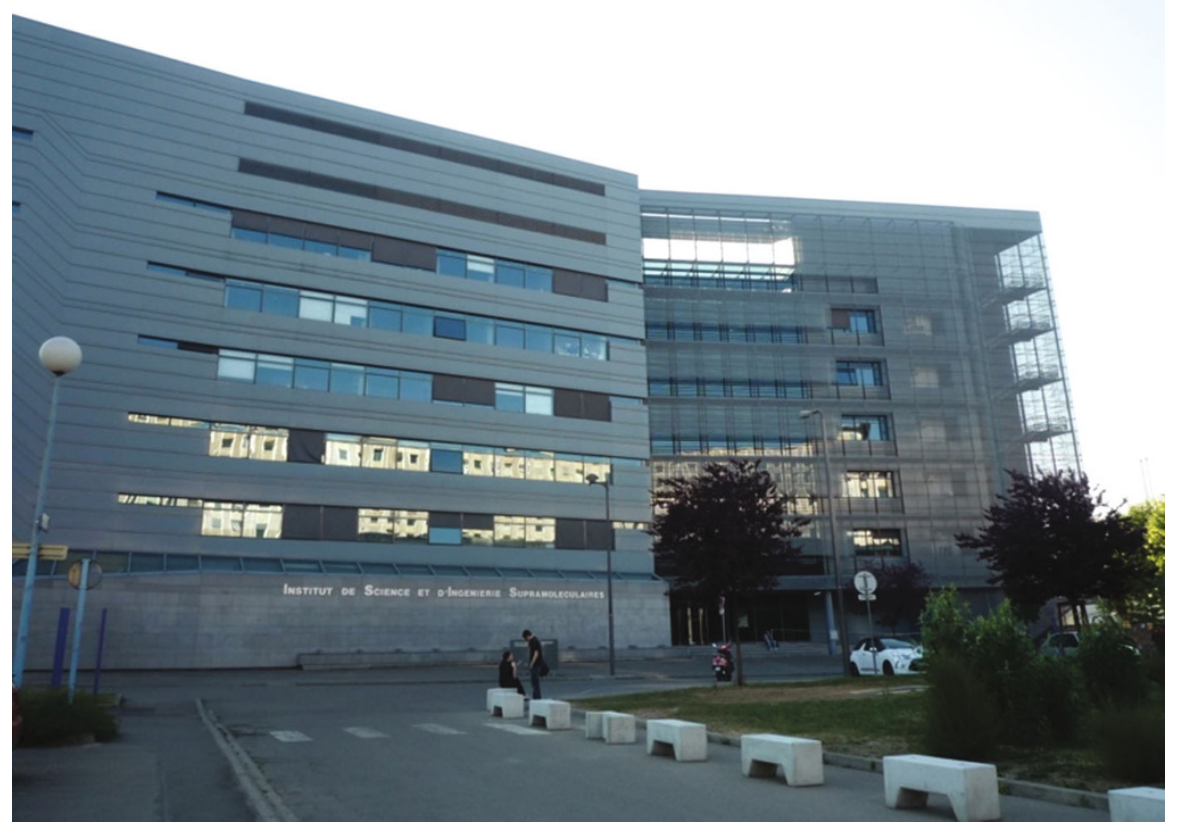

Fig. 2.2 The ISIS building at the University of Strasbourg

further development of his research, based on a vision he himself had defined: that of a scientific project incubator, where 'the most brilliant young researchers in the supramolecular sciences will be able to express themselves freely, before pursuing their career in other research centres' ${ }^{32}$ This new institute signified a major achievement in his career and was thought of as an organisational innovation in the French research scene. It was supported by the Louis Pasteur University in partnership with the CNRS and funded by the local government.

The entrance hall of the five-story building (Fig. 2.2) bears a plate with the engraving 'ISIS is the project of Jean-Marie Lehn, Nobel Prize for Chemistry, supported by the Louis Pasteur University in partnership with the CNRS'.

Such personalisation is quite rare in the world of French research. In a report to the Alsace Region in $1990,{ }^{33}$ Guy Ourisson noted that

chemistry research in Alsace presents very particular characteristics, which need to be properly identified in order to understand that the level of this research is not a result of

\footnotetext{
${ }^{32}$ Declaration by Claudie Haigneré, French Minister for Research and New Technologies, inauguration of the ISIS, 9 December 2002, http://discours.vie-publique.fr/notices/033000507.html. Accessed 1 March 2019.

${ }^{33}$ FR Service Archives de l'Université de Strasbourg /Guy Ourisson/GO 480/Livre Blanc de la recherche et de la technologie en Alsace, p. 30 (1990).
} 
Jean-Marie Lehn receiving the Nobel Prize, but the reason why this Nobel Prize was possible, without him having to leave the country!

The ISIS building was designed by the French architect Claude Vasconi (1940-2009). Vasconi was born in the same city as Lehn and was of the same generation. He graduated from the Ecole Nationale Supérieure des Arts et de l'Industrie in Strasbourg. ISIS' architecture was jointly designed with two purposes: first, priority was given to the horizontal circulation in a volume organised around a central atrium in order to meet a strong demand for decompartmentalising disciplines. As for a whole generation of science architecture in the 2000s (Yaneva 2010), the atrium became an important interactive space (a connecting mechanism, ibid., p. 143). The building invited the creation of new types of associations among researchers from different (sub-)disciplines or specialties and among public research and industry. A senior professor summarised it in this form:

A specialist in a discipline, a related area [to SMC], a platform. Four platforms and a fifth for common machines, this was [Jean-Marie Lehn's] concept. ${ }^{34}$

Second, ISIS was also conceived of as a 'transient' structure, where independent young researchers could work before they gained a permanent position in the academic system. The concept was that of a space where 'mobile professors' work/compete with each other. This particular setting refers to a phase in the researchers' careers rather than to the substance of their work (Normark 2015).

Based on Strasbourg's experience, public research organisations (e.g. CNRS, INSERM) and universities encouraged the creation of such 'research hotels' (hôtels à projets) in France. In Bordeaux, the European Institute of Chemistry and Biology (Institut Européen de Chimie et de Biologie, IECB) was built with a specific reference to Lehn's project. The local authorities provided support, as had happened in Alsace, and the IECB opened in 2003. The 'research hotels' model has since experienced ups and downs: the issue of incongruity between 'local' and foreign researchers that benefit from the provided resources to different degrees was also raised by an interviewee in Bordeaux.

\subsection{Concluding Remarks}

This chapter proposes a historical chronology in three periods, which corresponds to the way Jean-Marie Lehn describes his work. Starting from fieldwork and the prominence of an academic scholar in a specific place, I tried to de-centre the historical narrative from the heroic 'he' to the collaborative 'they' by looking at patterns of collaboration and co-authorship of an individual (Nye 2014). This

\footnotetext{
${ }^{34}$ Interview 5, 02/03/11.
} 
enabled me to understand the collective development of this specialty ${ }^{35}$ The chapter highlights a process of collective realisation through emphasis on a 'great man' and enrolment mechanisms (Callon and Law 1982). These achievements also came with the constitution of a mythology, which is vital to legitimise a disciplinary community (Nye 1993). I was able to measure the weight of the figurehead and the significance of the Nobel Prize as a symbolic resource: 80 per cent of interviewees spontaneously cited his name (or rather his first name, Jean-Marie) in the interviews. The analysis reveals how the local Alsatian culture also shaped the development of SMC. The influence of local conditions (and the special place of Strasbourg) is tangible in this historical reconstruction of emergence of SMC in France. The way scientists collectively used the institutional context at local, national, and international levels was crucial in the dynamics of emergence and institutionalisation.

The concepts and language of SMC can be to a large extent attributed to the scientific creativity of Lehn (Bowman-James et al. 2012, p. 1). His great innovation was to argue that the synthesis of molecules was primarily guided by new functions and essentially by the information contained in the molecules. Away from a growth model based on demarcation and constant differentiation, SMC found its place thanks to its conceptual developments and encouragement towards openness rather than confinement. This study borrows a lot from Mullins' work. The phasing resulting from the combination of scientometrics and the Mullins' model made the temporal processes visible, which were far from static: on the individual level, I've insisted on Lehn's multiple displacements, whether conceptual, methodological, or physical (such as periods abroad or marked by implementation of a new building). As far as the Strasbourg core was concerned, projects were multiple, as attested by the list of publications and the countless number of supramolecular systems that were created: cryptands, helicates, multicompartmental nanocylinders, 'grid-type' entities, ordered polymetallic arrays, etc. There was a strong material dimension to this emergence: the synthesis of new compounds, the contribution of models, and instrumental techniques like NMR and X-Ray diffraction, which were developed and made available in Strasbourg, ${ }^{36}$ led to a multitude of combinatorials. Temporalities were varied, from punctual to long-term disciplinary anchor. Using an approach privileging cognition (with a co-authorship model that emphasises the structure of communication), I argue that Lehn's career exemplifies the 'new disciplinarity', a form of disciplinary regime that is characterised by specific modes of temporality and displacement. Given the abundance of his activities, Lehn is difficult to situate in the typology discussed in Sect. 2.1.2 (I propose a mix of trajectories (2),

\footnotetext{
${ }^{35}$ There are limitations to this approach, which may not be extended to every case study: it is not always possible to identify a single person or group that originates a field; a Nobel Prize (that awards a maximum of three people) is not always awarded to fields that gain great prominence.

${ }^{36}$ The development of shared facilities has always been a priority of budgetary policies, as shown in the minutes of meetings (1966-1980) at the Institut de Chimie de Strasbourg. FR Service des archives de 1'Université de Strasbourg/Guy Ourssion/GO167/Gestion des Relations au sein de l'Institut de Chimie (1966-1980). Today the RTRA continues to competitively allocate important resources to shared facilities.
} 
(3), and (4)). The elements describing Stoddart's career path in the reference paper are too succinct to allow for a comparative analysis, suggesting a more detailed analysis (examining both epistemic and social emergence) is needed to refine the four patterns developed by Marcovich and Shinn in their 'new disciplinarity' model.

In this work, I have tried to make the circulation of concepts (but also of terms, methods, and visions) visible. These concepts were not fixed; 'they travel between disciplines, between individual scholars, between historical periods, and between geographically dispersed academic communities. Between disciplines, their meaning, reach, and operational value differ' (Bal 2002, p. 24). The emphasis on circulating entities makes it possible to reveal heterogeneous actor-networks in which contemporary technosciences are deployed, where concepts (a 'chemistry beyond molecules', the introduction of the notions of adaptation and evolution, etc.) or visions (that of mobile professors) can even materialise in buildings and institutions. The case study shows that disciplinary structures are very much alive, as evidenced by the allegiance of scientists to the discipline, which is coupled with the attention paid to its centrality. In light of the increasing complexity of scientific knowledge and activities, this investigation of SMC offers a perspective on how to live together as part of the 'new disciplinarity'.

Acknowledgments I wish to thank Pierre-Benoît Joly, Catherine Paradeise, Soraya Boudia, Morgan Meyer, and David Demortain, as well as the members of PrestEnce project, for their insightful comments and support. Earlier versions of this chapter have been discussed at conferences and in workshops and benefited from valuable comments and key inputs (in particular from Davide Donina, Susan Molyneux-Hodgson, Niki Vermeulen, and Karen Kastenhofer). I am also deeply grateful to the anonymous reviewers and to the interviewees.

This chapter is an output of the PrestEnce project funded by the Agence Nationale de la Recherche (ANR-09-SOC-011). This work has also received travelling support from the Société Chimique de France, Club d'Histoire de la Chimie, and from the IFRIS.

\section{References}

Bal, M. 2002. Travelling concepts in the humanities: A rough guide. Toronto: University of Toronto Press.

Bensaude-Vincent, B., and J. Simon. 2008. Chemistry: The impure science. London/Singapore: Hackensack/Imperial College Press. Distributed by World Scientific Pub.

Bensaude-Vincent, B., and I. Stengers. 2001. Histoire de la chimie. Paris: La Découverte.

Bertozzi, C.R. 2015. The centrality of chemistry. ACS Central Science 1 (1): 1-2.

Bertrand, E., and B. Bensaude-Vincent. 2011. Materials research in France: A short-lived national initiative (1982-1994). Minerva 49 (2): 191-214.

Bonneuil, C., and D. Pestre, eds. 2015. Histoire des sciences et des savoirs. 3. Le siècle des technosciences (depuis 1914). Paris: Éditions du Seuil.

Bowman-James, K., A. Bianchi, and E. García-España, eds. 2012. Anion coordination chemistry. Wiley-VCH-Verl: Weinheim.

Callon, M., and J. Law. 1982. On interests and their transformation: Enrolment and counterenrolment. Social Studies of Science 12 (4): 615-625.

Craig, J.E. 1984. Scholarship and nation building: The universities of Strasbourg and Alsatian society, 1870-1939. Chicago: University of Chicago Press. 
Cram, D.J. 1987. Nobel Lecture. Nobel Media AB 2019. https://www.nobelprize.org/uploads/2018/ 06/cram-lecture.pdf. Accessed 24 Feb 2019.

Cram, D.J., and J.M. Cram. 1974. Host-guest chemistry: Complexes between organic compounds simulate the substrate selectivity of enzymes. Science 183 (4127): 803-809.

Cram, Donald J., and J.M. Cram. 1994. Container molecules and their guests. Cambridge: Royal Soc. of Chemistry.

Crawford, E.T., and J. Olff-Nathan, eds. 2005. La science sous influence: l'université de Strasbourg enjeu des conflits franco-allemands, 1872-1945. Strasbourg: Nuée Bleue.

Cronin, B., D. Shaw, and K.L. Barre. 2004. Visible, less visible, and invisible work: Patterns of collaboration in 20th century chemistry. Journal of the American Society for Information Science and Technology 55 (2): 160-168.

Dance, I. 2003. What is supramolecular? New Journal of Chemistry 27 (1): 1-2.

Diederich, F. 2007. 40 years of supramolecular chemistry. Angewandte Chemie International Edition 46 (1-2): 68-69.

Gale, P.A. 2000. Supramolecular chemistry: From complexes to complexity. Philosophical Transactions of the Royal Society of London. Series A: Mathematical, Physical and Engineering Sciences 358 (1766): 431-453.

Gavroglou, K., and A. Simões. 2012. Neither physics nor chemistry: A history of quantum chemistry. Cambridge, MA: MIT Press.

Griffith, B.C., and N.C. Mullins. 1972. Coherent social groups in scientific change. Science 177 (4053): 959-964.

Heinze, T., R. Heidler, R.H. Heiberger, and J. Riebling. 2013. New patterns of scientific growth: How research expanded after the invention of scanning tunneling microscopy and the discovery of Buckminsterfullerenes: New patterns of scientific growth. Journal of the American Society for Information Science and Technology 64 (4): 829-843.

Jacob, C., ed. 2007. Lieux de savoir. Paris: Albin Michel.

Kleinpeter, E., and R.-E. Eastes. 2008. Comment je suis devenu chimiste. Paris: Le Cavalier bleu éd.

Kovac, J. 2002. Theoretical and practical reasoning in chemistry. Foundations of Chemistry 4 (2): 163. https://link.springer.com/article/10.1023\%2FA\%3A1016035726186. Accessed 03 May 2019.

Larivière, V., N. Desrochers, B. Macaluso, P. Mongeon, A. Paul-Hus, and C.R. Sugimoto. 2016. Contributorship and division of labor in knowledge production. Social Studies of Science 46 (3): 417-435.

Laudel, G. 2002. What do we measure by co-authorships? Research Evaluation 11 (1): 3-15.

Lehn, J.-M. 1978. Cryptates: Inclusion complexes of macropolycyclic receptor molecules. Pure and Applied Chemistry 50 (9-10): 871-892.

. 1980. Leçon inaugurale faite le vendredi 7 mars 1980, Collège de France, Chaire de chimie des interactions moléculaires. Paris: Collège de France.

- 1987. Nobel Lecture. Nobel Media AB 2019. https://www.nobelprize.org/uploads/2018/ 06/lehn-lecture.pdf. Accessed 24 Feb 2019.

1995. Supramolecular chemistry: Concepts and perspectives: A personal account built upon the George Fisher Baker lectures in chemistry at Cornell University [and] Lezioni Lincee, Accademia nazionale dei Lincei, Roma. Weinheim/New York: VCH.

- 2007. From supramolecular chemistry towards constitutional dynamic chemistry and adaptive chemistry. Chemical Society Reviews 36 (2): 151-160.

- 2017. Supramolecular chemistry: Where from? Where to? Chemical Society Reviews 46 (9): 2378-2379.

Lemaine, G., ed. 1976. Perspectives on the emergence of scientific disciplines. The Hague/Aldine: Chicago/Mouton.

Lenoir, T. 1997. Instituting science: The cultural production of scientific disciplines. Stanford University Press. 
Marcovich, A., and T. Shinn. 2011. Where is disciplinarity going? Meeting on the borderland. Social Science Information 50 (3-4): 582-606.

- 2014. Toward a new dimension: Exploring the nanoscale. Oxford: Oxford University Press.

McCray, W.P. 2005. Will small be beautiful? Making policies for our nanotech future. History and Technology 21 (2): 177-203.

Mullins, N.C. 1972. The development of a scientific specialty: The phage group and the origins of molecular biology. Minerva 10 (1): 51-82.

Newman, D. 2006. The lines that continue to separate us: Borders in our 'borderless' world. Progress in Human Geography 30 (2): 143-161.

Noël, M. 2019. Set of 897 publications released between 1961 and 2011 (Web of Knowledge request, Author=Lehn, JM), Mendeley Data, V1.

Normark, D. 2015. Flexibility or inexactitude? The 'Lab 60' at Karolinska Institutet: From medical disciplines towards the modern biomedical complex. Ambix 62 (2): 167-188.

Nye, M.J. 1993. From chemical philosophy to theoretical chemistry: Dynamics of matter and dynamics of disciplines, 1800-1950. Berkeley: University of California Press.

2014. Mine, thine, and ours: Collaboration and co-authorship in the material culture of the mid-twentieth century chemical laboratory. Ambix 61 (3): 211-235.

Olivier-Utard, F. 2010. L'université de Strasbourg de 1919 à 1939: s'ouvrir à l'international mais ignorer l'Allemagne. Les Cahiers de Framespa 6: 401.

Paradeise, C., and J.-C. Thoenig. 2013. Academic institutions in search of quality: Local orders and global standards. Organization Studies 34 (2): 189-218.

Raimbault, B., and P.-B. Joly. 2021. The emergence of technoscientific fields and the new political sociology of science (In this book).

Reinhardt, C., ed. 2001. Chemical sciences in the 20th century: Bridging boundaries. Weinheim/New York: Wiley-VCH.

Rohmer, M. 2006. Guy Ourisson (1926-2006). Angewandte Chemie International Edition 45 (48): 8088-8088.

Schummer, J. 2006. Gestalt switch in molecular image perception: The aesthetic origin of molecular nanotechnology in supramolecular chemistry. Foundations of Chemistry 8 (1): 53-72.

Servos, J.W. 1993. Research schools and their histories. Osiris 8: 2-15.

Siegel, J.S. 1996. Molecular collectives: Supramolecular chemistry. Science 271 (5251): 949-949.

Steed, J.W., and J.L. Atwood. 2009. Supramolecular chemistry. 2nd ed. Chichester: Wiley.

Stichweh, R. 1984. Zur Entstehung des modernen Systems wissenschaftlicher Disziplinen: Physik in Deutschland, 1740-1890 (1. Aufl.). Frankfurt am Main: Suhrkamp.

- 2001. Scientific disciplines, history of. In International encyclopedia of the social \& behavioral sciences, 13727-13731. Oxford: Elsevier.

—. 2013. Wissenschaft, Universität, Professionen: soziologische Analysen (Neuaufl.). Bielefeld: Transcript.

Teissier, P. 2010. Solid-state chemistry in France: Structures and dynamics of a scientific community since World War II. Historical Studies in the Natural Sciences 40 (2): 225-258.

van Brakel, J. 2000. Philosophy of chemistry: Between the manifest and the scientific image. Leuven: Leuven University Press.

Vicens, J., and Q. Vicens. 2011. Emergences of supramolecular chemistry: From supramolecular chemistry to supramolecular science. Journal of Inclusion Phenomena and Macrocyclic Chemistry 71 (3-4): 251-274.

Voillequin, B. 2008. Contribution à l'histoire de la catalyse en France (1944-2004). Dynamiques disciplinaires et régimes de production de savoir. Paris: Université Paris Nanterre.

Weber, J., ed. 2010. Interdisziplinierung? zum Wissenstransfer zwischen den Geistes-, Sozial- und Technowissenschaften. Bielefeld: Transcript.

Whitley, R. 1976. Umbrella and polytheistic scientific disciplines and their elites. Social Studies of Science 6 (3-4): 471-497. 
Woodward, R.B. 1973. The total synthesis of vitamin B12. Pure and Applied Chemistry 33 (1): $145-178$.

Yaneva, A. 2010. Is the atrium more important than the lab? Designer buildings for new cultures of creativity. In Geographies of science, ed. P. Meusburger, D. Livingstone, and H. Jöns, vol. 3, 139-150. Dordrecht: Springer Netherlands.

Open Access This chapter is licensed under the terms of the Creative Commons Attribution 4.0 International License (http://creativecommons.org/licenses/by/4.0/), which permits use, sharing, adaptation, distribution and reproduction in any medium or format, as long as you give appropriate credit to the original author(s) and the source, provide a link to the Creative Commons license and indicate if changes were made.

The images or other third party material in this chapter are included in the chapter's Creative Commons license, unless indicated otherwise in a credit line to the material. If material is not included in the chapter's Creative Commons license and your intended use is not permitted by statutory regulation or exceeds the permitted use, you will need to obtain permission directly from the copyright holder. 